\title{
An Analysis of Trade Specialization in Bangladesh, 1996-2011
}

\section{Md. Mehedi Hasan Sikdar}

Associate Professor, Department of Statistics, Patuakhali Science and Technology University, Dumki, Patuakhali-8602, BANGLADESH

E-mail for correspondence: mmhsikdar@gmail.com

\begin{abstract}
Trade specialization has been studied extensively, and many researchers try to explain the patterns of the specialization and different factors that determine it. By using the Revealed Symmetric Comparative Advantage Index and the Galtonian Regression Technique, this study tries to determine the industries with trade specialization and analyze the transformation of the pattern of trade specialization in Bangladesh in the period 1996-2011 to show how the export and import specialization of industries changed and to what extent the pattern of trade specialization in Bangladesh has been transformed during the last sixteen years. Empirical analysis showed that the export of Bangladesh consists mainly of the garment industry, and Bangladesh import products largely belong to the category of commodities for further production and the support of the exporting sector. From the Galtonian regression analysis of export and import specialization, it has been found that the level of export diversification is very low, relatively stable which is confirmed by the low mobility effect. Bangladesh's export specialization pattern is highly concentrated only in apparel products over the whole study period, and all other sectors contribute with a significantly smaller amount in total export share, but import is more diversified. For the development of the country, it is necessary to diversify its export basket.
\end{abstract}

Keywords: Trade specialization, Galtonian regression, RSCA, Garment Industry, Exporting Sector

\section{INTRODUCTION}

Trade liberalization and Economic transformation in Bangladesh was initiated when Bangladesh entered the South Asian Association for Regional Cooperation (SAARC) in 1985. Since then, international trade has played a vital role in the economy of Bangladesh. In the last twenty-five years, merchandise exports and imports of Bangladesh have increased greatly in quantity. The amount of total trade of Bangladesh rose almost ten times in the last twenty -seven years. From the initial US $\$ 4.87$ billion in 1985 , it reached US \$41.94 billion in 2011 (WB, 2013).

Exports of Bangladesh comprised mostly of raw jute and a few other agricultural products. But after liberalizing the economy of Bangladesh, export composition changed dramatically mainly concerning some sector policy changes such as export-import policy changes. ReadyMade-Garments (RMG) products emerged as the main export items of the country.

Even though the exports have experienced impressive growth, Bangladesh still has only a few manufacturing industries that contribute to the country's export, and thus diversification of its economic structure is necessary. The country's long-term development is therefore bound to the development of a broad specter of manufacturing industries, especially those in which Bangladesh has comparative advantage.

David Ricardo formulated the theory of comparative advantage in 1817. Comparative advantage has been an important concept in international trade, and it has been studied comprehensively in developed countries. Although comparative advantage is a simple concept, it combines several different aspects of an economy. According to Balassa (1965), "Comparative advantages appear to be the outcome of some factors, some measurable, others not, some easily pinned down, others less so" (p.116). However, he proposed an index to determine comparative advantage using observed data.

Using his index and with the help of the Galtonian regression technique, this study attempts to determine the industries with export and import specialization, to analyze the transformation of the pattern of trade specialization in Bangladesh and to answer the following 
questions: how the export and import specialization of industries changed and to what extent the pattern of trade specialization in Bangladesh has been transformed during the last sixteen years. Trade specialization has been studied extensively, and many researchers try to explain the patterns of the specialization and different factors that determine it. According to Bernatonyte and Normantiene (2009), a country`s specialization comes from utilizing its "comparative advantages and arising from differences in technology, innovativeness, and differences in factor endowments" (p.7).

In the case of measuring international specialization, there are various measures of international specialization used in the literature such as Revealed Comparative Advantage developed by Balassa (1965) using available post-trade data as autarkic prices or when production costs are unobservable. Other measures like the Michael index, the chi-square measure and the specialization vector from constant market share analysis.

Dalum, Laursen, and Villumsen (1998) used Revealed Symmetric Comparative Advantage (RSCA) and the Galtonian regression method to see the structural change in OECD countries export specialization. Laursen (2000) investigated export and technological specialization patterns of 19 OECD countries in the period of 1971-1991 using RSCA and the Galtonian regression method. Uchida and Cook (2005) conducted research concerning competitive advantage in East Asian countries. They considered technological and trade specialization and used symmetric revealed comparative advantage, symmetric technological comparative advantage, and Galtonian regression analysis. Sanidas and Shin (2010) compared six RCA indices with application to trade tendencies of East Asian Countries. Bayarjargal (2012) studied the Revealed Comparative Advantage of Mongolia for the years 19962007. Ullah and Inaba (2012) analyzed the dynamics of comparative advantage and export potentials in Bangladesh from 1990 to 2007. They used Normalized Revealed Comparative Advantage and product mapping.

From all the reviews, it appears that Symmetric Revealed Comparative Advantage Index and Galtonian Regression Technique regarding trade specialization are useful to see the changes in trade specialization of Bangladesh since many researchers from the reviews suggested this method as the most suitable one.

\section{Methodology and DATA}

\section{Measuring Specialization in international trade}

Balassa's Revealed Comparative Advantage Index (Balassa, 1965) is one of the most commonly used technique to analyze the export performance of a country. The present study uses the index for the international specialization patterns of Bangladesh. The index is now popularly known as the Revealed Comparative Advantage (RCA) index and is expressed as follows:
$\operatorname{RCA}_{i j}=\frac{\frac{x_{i j}}{\sum_{j} x_{i j}}}{\frac{\sum_{i} x_{i j}}{\sum_{\mathrm{i}} \Sigma_{j} x_{i j}}} \ldots \ldots$ (i)

Where,

$\mathrm{RCA}_{\mathrm{ij}}$ denotes the revealed comparative advantage index of country I in commodity group j

$X_{\text {ij }}$ symbolizes country I's total exports of commodity group j

$\sum_{j} X_{i j}$ represents country I's total exports of all commodity group

$\sum_{i} X_{i j}$ indicates world's total exports of commodity group $\mathrm{j}$

$\sum_{i} \sum_{j} X_{i j}$ stands for total exports of the world of all commodity group

Simply we can say that the numerator of equation (i) is percentage share of a given sector in national exports and the denominator is the percentage share of a given sector of the world's exports. Thus, the RCA index is a comparison of the national export structure with the world's export structure.

The RCA index takes a value between 0 and $+\infty$ thus it is a non-negative value. When RCA equals 1 for any particular sector in a particular country, the percentage share of that particular sector is identical to the world average. In the case that RCA is greater than 1, the specific country is said to be specialized in that specific sector and if the RCA value is less than 1 , then it is said to be not specialized in that sector. Import specialization is a similar indicator obtained by substituting imports to exports in equation (i).

Laursen (1998) develops a new index which is labeled as 'Revealed Symmetric Comparative Advantage' (RSCA) and is expressed as follows:

$\operatorname{RSCA}_{i j}=\frac{R C A_{i j}-1}{R C A_{i j}+1} \quad \ldots \ldots$ (ii)

The RSCA index ranges from -1 to +1 (or $-1 \leq R S C A_{i j} \leq+1$ ). Similar with the RCA index, RSCA can be interpreted like RSCA $_{i j ;}$ more than 0 implies country $i$ is specialized in product $\mathrm{j}$ and less than 0 means that country $\mathrm{i}$ is not specialized in product $j$. Mainly this kind of transformation meets the normality assumption more than the previous RCA index and has the advantage to perform regression analysis.

\section{Specification of the Model}

This study uses the method first used by John Cantwell (1989). The Galtonian Regression is a simple regression method which is as follows:

$\operatorname{RSCA}_{i j}{ }^{t}=\alpha+\beta \operatorname{RSCA}_{i j}{ }^{t-1}+\varepsilon_{i j}{ }^{t} \ldots \ldots$

Where

$t$ refers to the final period

$\mathrm{t}-1$ indicates the initial period

$\alpha$ and $\beta$ are intercept, slope respectively of the regression line 
$\varepsilon_{i j}{ }^{t}$ is error term and independent of $\operatorname{RSCA}_{i j}{ }^{\mathrm{t}-1}$

The above model is used to test the specialization trend by comparing two cross-sections at two different time periods both country and industry wise. In this study, the period of observation is from 1996 to 2011 because we are interested in trade specialization after the trade liberalization of Bangladesh. The whole period is divided into four sub-periods for the analysis:

Period I (1996-1999), Period II (2000-2003), Period III (20042007) and Period IV (2008-2011).

Here, we take a four-year average as one period because usually, index does not frequently change every year. Another reason for dividing the whole period into four sub-periods is that we want to examine the longest period IV-I, followed by the shorter IV-II and IV-III periods. Again, for each industry, the four-year average has been taken to get industry based stable export and import data.

The interpretation varies according to different values of the slope $(\beta)$. For example:

If $\beta=1$, then there is no change in the degree of specialization between two time periods

If $\beta>1$, then the economy has become more specialized in its area of specialization where it is already specialized and less specialized in product categories in which its specialization is low.

If $0<\beta<1$, then commodities with initially high values of RSCA experience a decline between the listed time periods while those with initially low scores experience growth over time, and, in general, the slope value falling in this range is an indication of the economy becoming more diversified.

If $\beta<0$, then there is a reversal in the ranking of the industries.

Again, the magnitude of $(1-\beta)$ is termed as the regression effect. A lower value of regression effects (i.e., a high value of $\beta$ ) implies the concentration of the specialization pattern, and a higher value indicates (i.e., a low value of $\beta$ ) a significant change in the pattern of specialization meaning diversification occurs significantly.

Now, the variance of the RSCA index at time' $t$ ' is denoted by $\sigma_{t}^{2}$ then from equation (iii) we have:

$\sigma_{t}^{2}=\beta^{2} \sigma_{t-1}^{2}+\sigma_{\varepsilon}^{2} \ldots \ldots \ldots$

and the square of the correlation co-efficient $\left(R^{2}\right)$ is given by:

$R^{2}=1-\left(\frac{\sigma_{\varepsilon}^{2}}{\sigma_{t}^{2}}\right)=\frac{\left(\sigma_{t}^{2}-\sigma_{\varepsilon}^{2}\right)}{\sigma_{t}^{2}} \ldots \ldots$

from (iv) and (v) it follows that:

$R^{2} \sigma_{t}^{2}=\sigma_{t}^{2}-\sigma_{\varepsilon}^{2}$

$\Rightarrow R^{2} \sigma_{t}^{2}=\beta^{2} \sigma_{t-1}^{2} \because \operatorname{from}(i v) \sigma_{t}^{2}-\sigma_{\varepsilon}^{2}=\beta^{2} \sigma_{t-1}^{2}$

$\Rightarrow \frac{\sigma_{t}^{2}}{\sigma_{t-1}^{2}}=\frac{\beta^{2}}{R^{2}} \Rightarrow \frac{\sigma_{t}}{\sigma_{t-1}}=\frac{|\beta|}{|R|} \ldots \ldots(\mathrm{vi})$
Hence, if $|\widehat{\beta}|=\widehat{|R|}$, the dispersion of a given distribution is unchanged.

If $|\widehat{\beta}|>\widehat{|R|}$, then the degree of specialization rises and falls when $|\widehat{\beta}|<\widehat{|R|}$.

The estimated Pearson correlation coefficient $\widehat{R}$, is a measure of the mobility of sectors up and down the RSCA distribution. A high value of $\widehat{R}$, indicates that the relative position of sectors is little changed, while a low value indicates that some industries are moving closer together and others further apart, quite possibly to the extent that the ranking of sectors changes. The magnitude of $(1-\hat{R})$ thus measures the 'mobility effects'.

A lower value for the mobility effect (i.e., high $\widehat{R}$ ) indicates the stability of a specialization pattern, whereas a high value (i.e., low $\hat{R}$ ) points to change.

A combination of stability (i.e., weak mobility effects) and concentration (weak or negative regression effect) suggests a strengthening of an established pattern of specialization. Conversely, a combination of change and diversification implies a change in the pattern of specialization.

\section{Data}

The present study uses commodity trade data of Standard International Trade Classification (SITC) Revision 3 at the three-digit level available in the United Nations Conference on Trade and development (UNCTADSTAT, 2013). For calculation of RCA and RSCA indexes, the trade data were collected for 16 years (1996-2011). This study period has been chosen because we are interested in trade specializations after the trade liberalization of Bangladesh.

\section{RESULtS AND Discussion}

\section{Regression Analysis of Export Specialization patterns of Bangladesh}

Export specialization of Bangladesh is presented in Table 1 , and it is calculated by applying equation (iii). The hypothesis $\hat{\beta}=1$ an unchanged pattern of RSCA was tested and is statistically significant at the 0.01 level for all periods of the economy. The extent of specialization increases for all periods since $\hat{\beta}$ has a higher value than $\hat{R}$. Regarding diversification, the analysis of the longer period (IV-I and IV-II) shows that Bangladesh experienced a very small level of diversification and changed its export specialization as its regression effect is relatively high compared to the third period. But in the case of the shorter period (IV-III), the economy becomes more specialized in the area of specialization where Bangladesh is already specialized, and it is less specialized in those industries where initial specialization is low. The estimated coefficient $(\hat{R})$ for the whole periods is high, which is an indication that the relative position of industries changes a little, meaning export specialization of Bangladesh is relatively stable and is also confirmed by the low mobility effect. 
Table 1: Export Specialization Indices of Bangladesh

\begin{tabular}{|c|c|c|c|c|c|c|}
\hline $\mathbf{p}$ & $\boldsymbol{\alpha}$ & $\boldsymbol{\beta}$ & $\mathbf{R}$ & $\begin{array}{c}\text { Degree of } \\
\text { Specialization }\end{array}$ & $\begin{array}{c}\text { Regression } \\
\text { Effect }\end{array}$ & $\begin{array}{c}\text { Mobility } \\
\text { Effect }\end{array}$ \\
\hline & & & & $(\beta / \mathrm{R})$ & $(1-\beta)$ & $(1-\mathrm{R})$ \\
\hline IV-I & 0.01 & $0.92^{* * *}$ & 0.86 & 1.07 & 0.08 & 0.14 \\
\hline & $(0.03)$ & $(0.03)$ & & & & \\
\hline IV-II & $0.08^{* * *}$ & $0.99^{* * *}$ & 0.90 & 1.10 & 0.01 & 0.10 \\
\hline & $(0.03)$ & $(0.03)$ & & & & \\
\hline IV-III & $0.04^{* * *}$ & $1.01^{* * *}$ & 0.97 & 1.04 & -0.01 & 0.03 \\
\hline & $(0.01)$ & $(0.02)$ & & & & \\
\hline
\end{tabular}

Note: Period I = 1996 - 1999, Period II = $2000-2003$, Period III $=2004-2007$ and Period IV $=2008-2011$. Ho: $\beta=1$ and ${ }^{* * *}$ denote significant at $1 \%$ level of significance and the quantities in parentheses below are standard errors.

\section{Export Share and Industries with Specialization}

The regression analysis in Table 1 shows the extent of the increase of export specialization in Bangladesh. This is also evident from Table 2 which represents the top ten industries with the highest export share and RSCA in four time periods.

Only 12 industries contributing to total export share over one percent and 21 industries have RSCA more than zero out of 194 industries in the initial period 1996-1999. However, the number becomes 11, 9, and 11 in having export share more than one and 19, 25 and 26 in having RSCA over zero in the period 2000-2003, 2004-2007 and 2008-2011 respectively.

Furthermore, Articles of apparel, clothing access, excluding textile (848) lost its top ten positions of export share from the third period. Men's clothing of textile fabrics, not knitted (841) had the highest export share in the first and second period, but it is replaced by Articles of apparel of textile fabrics (845) from the third period until the end period, and reached its highest position regarding export share. The share of Men's clothing of textile fabrics, not knitted (841), Women's clothing of textile fabrics (842), Men's or boy's clothing of textile, knitted (843), Women's clothing of textile, knitted (844), Articles of apparel of clothing access, excluding textile (848) all together consist of over a 70 percent share of total export of Bangladesh in the initial period where it becomes over 75 percent in the end period without Articles of apparel of clothing access, excluding textile (848) whereas it is noticeable that world share of the above five products was 2.09 percent in the end period.

Table 2: Top Ten Highest Export Share and RSCA

\begin{tabular}{|c|c|c|c|c|c|c|c|c|c|c|c|c|}
\hline \multicolumn{4}{|c|}{ Top ten } & \multicolumn{3}{c|}{ Top ten } & \multicolumn{3}{c|}{ Top ten } & \multicolumn{3}{c|}{ Top ten } \\
\hline \multicolumn{3}{|c|}{ Period I (1996-1999) } & \multicolumn{2}{c|}{ Period II (2000-2003) } & \multicolumn{3}{c|}{ Period III (2004-2007) } & \multicolumn{3}{c|}{ Period IV (2008-2011) } \\
\hline Rank & Products & $\begin{array}{c}\text { Export } \\
\text { Share }\end{array}$ & RSC A & Products & $\begin{array}{c}\text { Export } \\
\text { Share }\end{array}$ & RSC A & Products & $\begin{array}{c}\text { Export } \\
\text { Share }\end{array}$ & RSC A & Products & $\begin{array}{c}\text { Export } \\
\text { Share }\end{array}$ & \begin{tabular}{c} 
RSC A \\
\hline 1
\end{tabular} \\
\hline 241 & 31.08 & 0.95 & 841 & 27.62 & 0.95 & 845 & 31.73 & 0.94 & 845 & 31.84 & 0.95 \\
\hline 2 & 845 & 19.81 & 0.90 & 845 & 26.78 & 0.92 & 841 & 23.31 & 0.96 & 841 & 22.18 & 0.96 \\
\hline 3 & 842 & 12.65 & 0.89 & 842 & 14.54 & 0.91 & 842 & 12.38 & 0.91 & 842 & 10.45 & 0.91 \\
\hline 4 & 036 & 5.90 & 0.90 & 036 & 5.01 & 0.90 & 843 & 4.92 & 0.94 & 843 & 5.60 & 0.94 \\
\hline 5 & 658 & 3.54 & 0.85 & 658 & 3.59 & 0.85 & 036 & 4.09 & 0.91 & 844 & 5.35 & 0.90 \\
\hline 6 & 611 & 3.29 & 0.84 & 843 & 3.20 & 0.89 & 844 & 3.88 & 0.87 & 658 & 3.72 & 0.85 \\
\hline 7 & 843 & 2.98 & 0.88 & 611 & 3.60 & 0.84 & 658 & 3.24 & 0.84 & 036 & 3.22 & 0.90 \\
\hline 8 & 844 & 2.51 & 0.77 & 844 & 2.84 & 0.81 & 611 & 2.23 & 0.84 & 651 & 2.13 & 0.74 \\
\hline 9 & 848 & 1.71 & 0.76 & 848 & 1.57 & 0.73 & 651 & 1.58 & 0.61 & 611 & 1.55 & 0.83 \\
\hline 10 & 651 & 1.69 & 0.47 & 651 & 1.48 & 0.49 & 851 & 0.98 & 0.22 & 562 & 1.32 & 0.54 \\
\hline & & 85.16 & & & 90.23 & & & 88.34 & & & 87.36 & \\
\hline
\end{tabular}

Source: Author's Calculation, 2013

To better understand the changes in the export share, Figure 1 presents a more detailed representation of main apparel products specialized in export of Bangladesh in the last 16 years. From the results presented in Table 2 and Figure 1, we can conclude that Bangladesh's export specialization pattern is highly concentrated only in apparel products over the whole study period and all other sectors contribute with a significantly smaller amount in total export share.

Another interesting point can be observed in Figure 1. In the case of Men's clothing of textile fabrics, not knitted (841), its RSCA is more or less constant over the whole study period, but the export share of Bangladesh is continuously decreasing, meaning that the world export of
Men's clothing of textile fabrics, not knitted (841) was also decreasing. On the other hand, in the case of Men's or boy's clothing of textile, knitted (843), Women's clothing of textile, knitted (844) and Articles of apparel of textile fabrics (845) their RSCA is constant and export share is continuously increasing, which is an indication that world share of these products is also increasing during the entire period of study. 

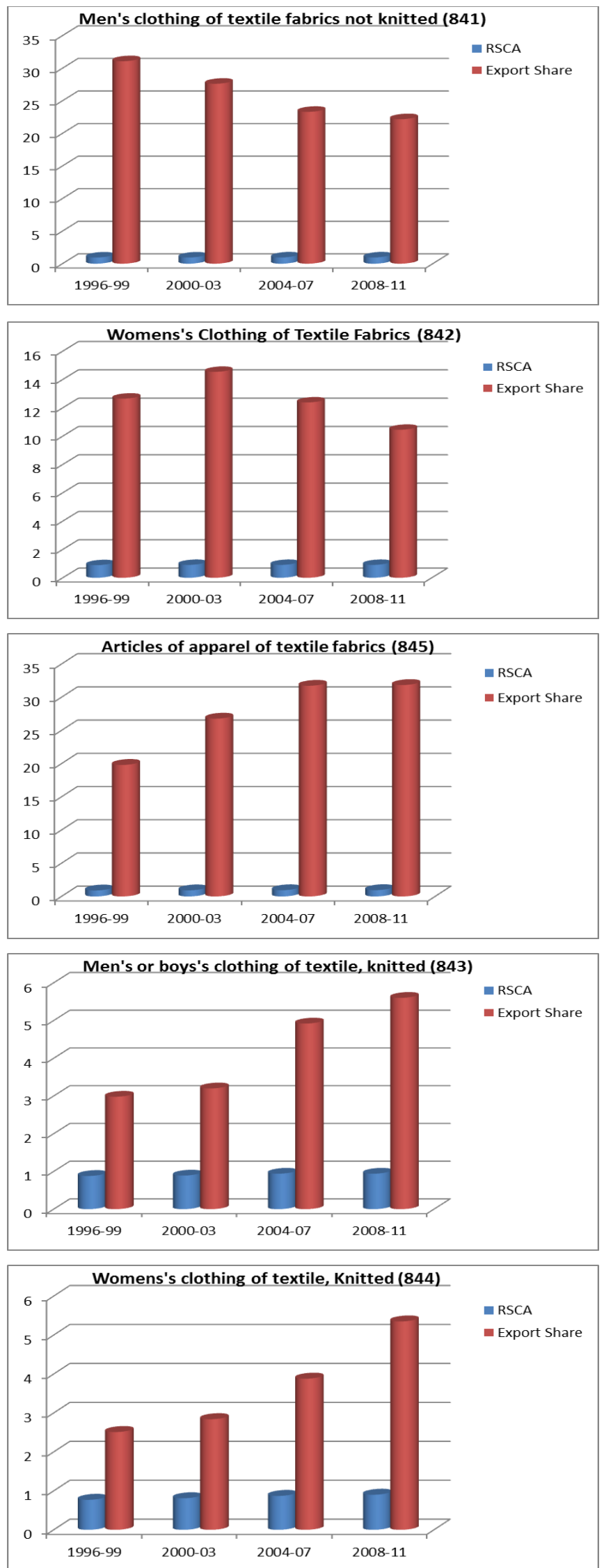

Figure 1: Apparel Industries that are specialized in export of Bangladesh during 1996-2011

\section{Regression Analysis of Import Specialization patterns of Bangladesh}

Import specialization of Bangladesh is presented in Table 3 , and it is also calculated by applying equation (iii). The hypothesis $\hat{\beta}=1$ an unchanged pattern of import RSCA was tested and is statistically significant at the 0.01 level for all periods of the economy. The extent of import specialization increases for all periods since $\hat{\beta}$ has a higher value than $\hat{R}$.

Table 3: Import Specialization Indices of Bangladesh

\begin{tabular}{|c|c|c|c|c|c|c|}
\hline Periods & $\boldsymbol{\alpha}$ & $\boldsymbol{\beta}$ & $\mathbf{R}$ & $\begin{array}{c}\text { Degree of } \\
\text { Specialization }\end{array}$ & $\begin{array}{c}\text { Regression } \\
\text { Effect }\end{array}$ & $\begin{array}{c}\text { Mobility } \\
\text { Effect }\end{array}$ \\
\hline & & & & $(\beta / \mathrm{R})$ & $(1-\beta)$ & $(1-\mathrm{R})$ \\
\hline IV-I & 0.00 & $0.87^{* * *}$ & 0.84 & 1.04 & 0.13 & 0.16 \\
\hline & $(0.02)$ & $(0.04)$ & & & & \\
\hline IV-II & -0.04 & $0.93^{* * *}$ & 0.90 & 1.03 & 0.07 & 0.10 \\
\hline & $(0.02)$ & $(0.03)$ & & & & \\
\hline IV-III & 0.01 & $0.99^{* * *}$ & 0.97 & 1.02 & 0.01 & 0.03 \\
\hline & $(0.01)$ & $(0.02)$ & & \multicolumn{2}{|c|}{} \\
\hline
\end{tabular}

Note: Period I = 1996 - 1999, Period II = $2000-2003$, Period $\mathrm{III}=2004-2007$ and Period IV $=2008-2011$. Ho: $\beta=1$ and $* * *$ denote significant at $1 \%$ level of significance and the quantities in parentheses below are standard errors

Regarding diversification, import is more diversified compared to export as values of $\hat{\beta}$ for all periods is less than export. But like export specialization, Bangladesh's import specialization is also relatively stable in the whole study period which is also confirmed by the low mobility effects.

\section{Import Share and Industries with Specialization}

Table 4 below represents the top ten industries with the highest import share and RSCA in four time periods. Only 20 industries contribute to total import share over one percent, and 67 industries have RSCA more than zero out of 227 industries in the initial period 1996-1999.

However, the number becomes 23, 22, and 24 in having import share more than one and 78, 76 and 84 in having import RSCA over zero in the period 2000-2003, 2004-2007 and 2008-2011 respectively which is much more than export.

From Table 4 we also can see that the top ten import industries are having import share on an average almost 40 percent of total import whereas in the case of top ten exporting industries it is almost 88 percent export share in its total export in the entire study period.

So we can conclude that Bangladesh's import specialization is more diversified compared to export and it can be stated that the most imported products in Bangladesh belong to the category of commodities for further production and for the support of exporting sectors for example Cotton fabrics (652), Cotton (263), Textile and leather machinery (724) and Textile yarn (651) etc. 
Table 4: Top Ten Highest Import Share and RSCA

\begin{tabular}{|c|c|c|c|c|c|c|c|c|c|c|c|c|}
\hline \multicolumn{4}{|c|}{ Top ten } & \multicolumn{3}{c|}{ Top ten } & \multicolumn{3}{c|}{ Top ten } & \multicolumn{2}{c|}{ Top ten } \\
\hline \multicolumn{3}{|c|}{ Period I (1996-1999) } & \multicolumn{2}{c|}{ Period II (2000-2003) } & \multicolumn{2}{c|}{ Period III (2004-2007) } & \multicolumn{2}{c|}{ Period IV (2008-2011) } \\
\hline Rank & Products & $\begin{array}{c}\text { Import } \\
\text { Share }\end{array}$ & RSC A & Products & $\begin{array}{c}\text { Import } \\
\text { Share }\end{array}$ & RSC A & Products & $\begin{array}{c}\text { Import } \\
\text { Share }\end{array}$ & RSC A & Products & $\begin{array}{l}\text { Import } \\
\text { Share }\end{array}$ & \begin{tabular}{c} 
RSC A \\
\hline 1
\end{tabular} \\
\hline 2 & 652 & 6.58 & 0.89 & 652 & 6.52 & 0.91 & 334 & 8.24 & 0.43 & 334 & 6.24 & 0.14 \\
\hline 3 & 651 & 5.81 & 0.80 & 334 & 5.53 & 0.42 & 652 & 5.65 & 0.92 & 652 & 5.71 & 0.94 \\
\hline 4 & 334 & 4.02 & 0.80 & 653 & 5.19 & 0.85 & 724 & 4.24 & 0.89 & 263 & 4.30 & 0.94 \\
\hline 5 & 673 & 3.70 & 0.73 & 263 & 3.61 & 0.94 & 764 & 3.93 & 0.08 & 724 & 4.23 & 0.91 \\
\hline 6 & 421 & 3.27 & 0.86 & 724 & 3.04 & 0.81 & 651 & 3.93 & 0.83 & 562 & 3.94 & 0.80 \\
\hline 7 & 041 & 2.80 & 0.78 & 421 & 2.36 & 0.87 & 422 & 3.18 & 0.91 & 651 & 3.75 & 0.85 \\
\hline 8 & 263 & 2.76 & 0.86 & 673 & 2.20 & 0.64 & 653 & 3.11 & 0.83 & 042 & 2.94 & 0.90 \\
\hline 9 & 724 & 2.72 & 0.74 & 041 & 2.19 & 0.79 & 793 & 2.41 & 0.68 & 764 & 2.83 & -0.05 \\
\hline 10 & 042 & 2.68 & 0.82 & 793 & 2.05 & 0.66 & 041 & 2.22 & 0.83 & 793 & 2.81 & 0.69 \\
\hline & & 39.84 & & & 37.01 & & & 41.07 & & & 41.01 & \\
\hline
\end{tabular}

Source: Author's Calculation, 2013

\section{Discussion}

After investigating both export and import specialization during the period 1996-2011, we found an interesting and important relationship between both specializations which is presented in Table 5. The relationship between export and import specialization of Bangladesh during two periods 1996-1999 and 2008-2011 can also be observed from Graph 2 and Graph 3. Graphs used in this analysis are separated into four quadrants at the points $(0,0)$, and each part is divided and represented as follows:

- The upper right quadrant - industries that are specialized in both export and import, meaning that these industries have cumulative patterns of trade specialization. Also, the industries that are in this quadrant indicate the existence of intra-industry trade.

- The lower right quadrant - industries that are specialized in import but not in export, meaning that the industries that lost its comparative advantage and now are in the position of comparative disadvantage.
- The upper left quadrant - industries that are specialized in export but not in import, meaning that these industries have gained the comparative advantage. All the industries in this quadrant are export-oriented.

- The lower left quadrant - industries that are not specialized in either import or export, meaning that these industries are using domestic resources and meeting domestic demand, but are not for international trade.

Higher levels of Bangladesh's export and import specialization in the initial period (1996-1999) are found in Textile yarn (651), Cotton fabrics, woven (652), other textile fabrics, woven (654) and Special yarn, special textile fabrics (657). In the end period (2008-2011), the above mentioned four industries continued to have both specializations because textile yarn, cotton fabrics, textile fabrics and special yarn are the main input for the ready-made garments industry, so these industries show a relatively cumulative or established pattern of both specializations.

Table 5: Export-Import Share and their specialization together

\begin{tabular}{|c|c|c|c|c|c|c|c|c|c|c|c|c|c|c|c|c|}
\hline & \multicolumn{4}{|c|}{ Export Share } & \multicolumn{4}{|c|}{ Export RSCA } & \multicolumn{4}{c|}{ Import Share } & \multicolumn{3}{c|}{ Import RSCA } \\
\hline $\begin{array}{c}\text { Product } \\
\text { Code }\end{array}$ & $\begin{array}{c}\text { Period } \\
\text { I }\end{array}$ & $\begin{array}{c}\text { Period } \\
\text { II }\end{array}$ & $\begin{array}{c}\text { Period } \\
\text { III }\end{array}$ & $\begin{array}{c}\text { Period } \\
\text { IV }\end{array}$ & $\begin{array}{c}\text { Period } \\
\text { I }\end{array}$ & $\begin{array}{c}\text { Period } \\
\text { II }\end{array}$ & $\begin{array}{c}\text { Period } \\
\text { III }\end{array}$ & $\begin{array}{c}\text { Period } \\
\text { IV }\end{array}$ & $\begin{array}{c}\text { Period } \\
\text { I }\end{array}$ & $\begin{array}{c}\text { Period } \\
\text { II }\end{array}$ & $\begin{array}{c}\text { Period } \\
\text { III }\end{array}$ & $\begin{array}{c}\text { Period } \\
\text { IV }\end{array}$ & $\begin{array}{c}\text { Period } \\
\text { I }\end{array}$ & $\begin{array}{c}\text { Period } \\
\text { II }\end{array}$ & $\begin{array}{c}\text { Period } \\
\text { III }\end{array}$ & $\begin{array}{c}\text { Period } \\
\text { IV }\end{array}$ \\
\hline 611 & 3.29 & 3.06 & 2.23 & 1.55 & 0.84 & 0.84 & 0.84 & 0.83 & 0.07 & 0.08 & 0.15 & 0.18 & -0.59 & -0.54 & -0.14 & 0.15 \\
\hline 612 & 0.01 & 0.01 & 0.01 & 0.02 & -0.31 & -0.56 & -0.54 & -0.12 & 0.01 & 0.01 & 0.01 & 0.01 & -0.66 & -0.62 & -0.58 & -0.51 \\
\hline 613 & 0.00 & 0.00 & 0.00 & 0.00 & -0.91 & -0.96 & -1.00 & -1.00 & 0.00 & 0.00 & 0.00 & 0.00 & -0.94 & -0.99 & -0.92 & -0.95 \\
\hline 651 & 1.69 & 1.48 & 1.58 & 2.13 & 0.47 & 0.49 & 0.61 & 0.74 & 5.81 & 4.32 & 3.93 & 3.75 & 0.80 & 0.79 & 0.83 & 0.85 \\
\hline 652 & 0.70 & 0.39 & 0.87 & 0.81 & 0.24 & 0.03 & 0.39 & 0.61 & 6.58 & 6.52 & 5.65 & 5.71 & 0.89 & 0.91 & 0.92 & 0.94 \\
\hline 653 & 0.40 & 0.12 & 0.09 & 0.04 & -0.27 & -0.61 & -0.56 & -0.70 & 5.02 & 5.19 & 3.11 & 2.55 & 0.80 & 0.85 & 0.83 & 0.85 \\
\hline 654 & 1.55 & 1.03 & 0.54 & 0.49 & 0.79 & 0.76 & 0.68 & 0.75 & 0.19 & 0.32 & 0.15 & 0.13 & 0.07 & 0.40 & 0.20 & 0.34 \\
\hline 655 & 0.07 & 0.06 & 0.01 & 0.03 & -0.60 & -0.64 & -0.86 & -0.72 & 1.97 & 1.92 & 1.31 & 1.24 & 0.76 & 0.80 & 0.77 & 0.79 \\
\hline 656 & 0.02 & 0.03 & 0.07 & 0.04 & -0.65 & -0.58 & -0.08 & -0.14 & 0.53 & 0.51 & 0.40 & 0.43 & 0.71 & 0.71 & 0.70 & 0.78 \\
\hline 657 & 0.60 & 0.39 & 0.35 & 0.36 & 0.20 & 0.04 & 0.10 & 0.15 & 0.91 & 0.95 & 0.57 & 0.44 & 0.44 & 0.50 & 0.37 & 0.30 \\
\hline 658 & 3.54 & 3.59 & 3.24 & 3.72 & 0.85 & 0.85 & 0.84 & 0.85 & 0.16 & 0.15 & 0.09 & 0.09 & -0.26 & -0.35 & -0.58 & -0.55 \\
\hline 659 & 0.09 & 0.02 & 0.03 & 0.05 & -0.37 & -0.72 & -0.56 & -0.30 & 0.01 & 0.02 & 0.02 & 0.02 & -0.87 & -0.76 & -0.73 & -0.61 \\
\hline 724 & 0.01 & 0.01 & 0.02 & 0.03 & -0.94 & -0.91 & -0.84 & -0.74 & 2.72 & 3.04 & 4.24 & 4.23 & 0.74 & 0.81 & 0.89 & 0.91 \\
\hline 841 & 31.08 & 27.62 & 23.31 & 22.18 & 0.95 & 0.95 & 0.96 & 0.96 & 0.09 & 0.20 & 0.13 & 0.02 & -0.79 & -0.58 & -0.69 & -0.89 \\
\hline \hline
\end{tabular}




\begin{tabular}{|c|c|c|c|c|c|c|c|c|c|c|c|c|c|c|c|c|}
\hline 842 & 12.65 & 14.54 & 12.38 & 10.45 & 0.89 & 0.91 & 0.91 & 0.91 & 0.05 & 0.12 & 0.13 & 0.07 & -0.89 & -0.76 & -0.72 & -0.76 \\
\hline 843 & 2.98 & 3.20 & 4.92 & 5.60 & 0.88 & 0.89 & 0.94 & 0.94 & 0.05 & 0.07 & 0.03 & 0.01 & -0.67 & -0.51 & -0.69 & -0.86 \\
\hline 844 & 2.51 & 2.84 & 3.88 & 5.35 & 0.77 & 0.81 & 0.87 & 0.90 & 0.11 & 0.04 & 0.02 & 0.01 & -0.62 & -0.77 & -0.85 & -0.90 \\
\hline 845 & 19.81 & 26.78 & 31.73 & 31.84 & 0.90 & 0.92 & 0.94 & 0.95 & 0.23 & 0.16 & 0.15 & 0.05 & -0.68 & -0.76 & -0.75 & -0.88 \\
\hline 846 & 0.21 & 0.16 & 0.11 & 0.12 & -0.06 & -0.12 & -0.19 & -0.13 & 0.76 & 1.10 & 0.85 & 0.61 & 0.47 & 0.69 & 0.68 & 0.59 \\
\hline 848 & 1.71 & 1.57 & 0.93 & 0.60 & 0.76 & 0.73 & 0.67 & 0.58 & 0.14 & 0.13 & 0.10 & 0.06 & -0.30 & -0.29 & -0.34 & -0.45 \\
\hline 851 & 0.90 & 0.81 & 0.98 & 1.09 & 0.01 & 0.04 & 0.22 & 0.27 & 0.15 & 0.16 & 0.17 & 0.15 & -0.74 & -0.67 & -0.61 & -0.62 \\
\hline & 83.81 & 87.71 & 87.30 & 86.51 & & & & & 25.51 & 24.98 & 21.18 & 19.75 & & & & \\
\hline
\end{tabular}

Looking into the main exporting industries in Table 5 which is also presented in Figure 2 and Figure 3, we see that industries that gained export specialization in the initial period like Made-up textile articles (658), Men's clothing of textile fabrics not knitted (841), Women/girl clothing woven (842), Men's/boys's wear knit (843), Women's/girl's wear knitted (844), Articles of apparel of textile fabrics (845) and Articles of apparel, clothing access, excluding textile (848) also remained specialized in export in the end period. All these products are classified as unskilled labor intensive, according to the product classification by Empirical Trade Analysis (ETA, 2013).

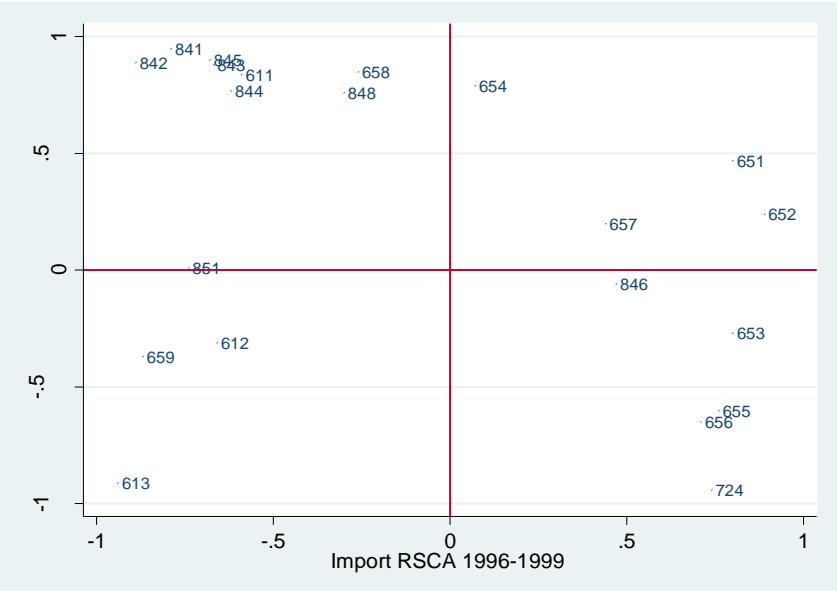

Figure 2: Export RSCA 1996-1999

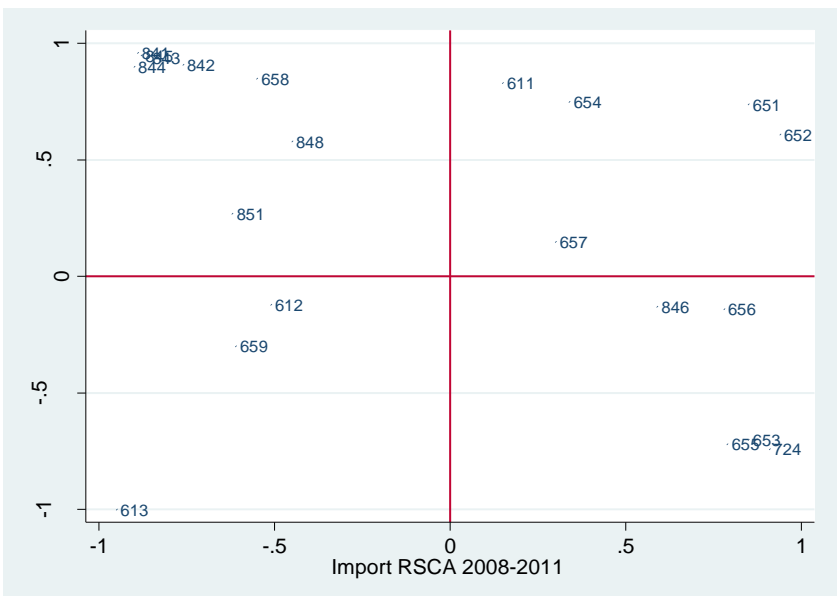

Figure 3: Export RSCA 2008-2011

Bangladesh has abundant cheap labor force. According to Bangladesh Garment Manufacturers and Exporters (2013), out of 4 million workers, 80 percent are women. Although they are unskilled with low education, they often work overtime whenever necessary. These two factors represent an important contribution to export specialization of the industry mentioned above. Also, energy cost in Bangladesh is low.

Bangladesh had a very good opportunity to enter the European and U.S. market through a Multi-fiber Agreement and Generalised System Preference. With the important EU and US markets, there is also a self-sustained domestic market of 154.70 million people with a growth rate of 1.2 percent, giving significant support to the industry.

The Government of Bangladesh also announced very favorable policies for these industries. Important export incentives were taken, and the garment industry was the biggest beneficiaries. The exporters are benefiting from the duty free import of machinery, raw materials and inputs needed for export production, back to back letter of credits (allowing exporters to open $\mathrm{L} / \mathrm{Cs}$ for the required import of raw materials against their export $\mathrm{L} / \mathrm{Cs}$ ), cash subsidies, interest rate subsidies, tax holidays, income tax rebates, retention of earnings in foreign currency etc.

The establishment of special economic zones for exporting goods like Bangladesh Export Processing Zone where infrastructure, different supporting services, and facilities are provided attracts foreign direct investments in these industries. In the year 1996 joint venture investment in textile (Hats \& Caps, Knit Garments, Ready-made Garments, Specialised textile, Textile spinning) was US\$ 30.721 million whereas it was US\$ 205.421 million in the year 2008 (BOI, 2010). As a result, export of ready-made garments increases tremendously from US\$ 3001.25 million in the year 1996-97 to US\$ 19089.69 million in the year 2011-12 (BGMEA, 2013).

Taking a closer look between the initial period from 19961999 and end period from 2008-2011, an interesting change occurs in two sectors.

The first one is the movement from the upper left to the upper right quadrant: Leather (611). It had high export specialization in the initial period and there is also an evident raise in import specialization in the final period, meaning that leather became specialized in both export and import. Bangladesh is a predominantly agricultural country with over 25 million cattle \& buffaloes and 17 million goats \& sheep (BBS, 2011) and has traditionally remained an important producer of wet-blue (unfinished) 
and crust (finished) leather. This industry is an old manufacturing sub-sector because of the availability of raw materials (hides and skin). The positive development of the sector was initiated by the major policy reform that took place in 1980-81 (DILF, 2000). In the industrial policy of 2005, this sector was considered as a thrust sector of the economy. Recently, the government of Bangladesh has taken some reform programs providing infrastructural facilities to the tannery entrepreneurs. The development and modernization of the tannery industry are going on to attract more external investment, to increase production, export and generating employment opportunities (BSCIC, 2013). In the financial year of 2011-2012, this sector experienced export growth of 79.29 percent and export increased to $\$ 73.27$ million in the first half of the financial year 2012-2013 compared to the previous financial year which was $\$ 35.39$ million (Haque, 2013). This sector also enjoys duty-free imports of raw materials and machinery for export-oriented leather goods. As a previously established export industry, with important support from the government, this sector is getting import specialization, and consequently, getting stronger in export specialization.

The second sector of change is the movement from the lower left to the upper left quadrant: Footwear (851). It is a new emerging industry, with a raise in export specialization. Footwear is a growing sector of Bangladesh, and its value addition is also increasing. Export of footwear grew by 65.45 percent from the year 1995 to the year 2011, and it occupied 0.60 percent of manufacturing GDP value addition in the year 1995 but 0.90 percent in the financial year 2009-10 (calculation used data from UNCTAD and BBS, 2011). This shows that the footwear industry is a promising sector gaining its export advantage in the end period of the study.

Again in Figure 2 and Figure 3 the industries in the lower right quadrant are specialized only in import. Among these industries Fabrics, woven, of man-made fabrics (653), Knitted or crocheted fabrics (655), Tulles, trimmings, lace, ribbons and other small wares (656) and Clothing accessories of textile fabrics (846) are material for the production of garments products. The other industry, Textile and leather machinery and parts (724) are also related to the input of garment production and at the same time for leather production.

From the above results and discussion, we can conclude that both export and import specialization of Bangladesh is mainly concentrated in the garment and its supporting industries.

\section{CONCLUSION}

The first objective of this study was to determine the industries with export and import specialization in Bangladesh, and to answer the question of how these industries changed in the period from 1996-2011.

The analysis has revealed that 21 out of 194 industries were specialized in export in the initial period 1996-1999. This number becomes 19, 25 and 26 in the period 2000-2003, 2004-2007 and 2008-2011 respectively. The share of Men's clothing of textile fabrics, not knitted (841), Women's clothing of textile fabrics (842), Men's or boy's clothing of textile, knitted (843), Women's clothing of textile, knitted (844), Articles of apparel of clothing access, excluding textile (848) all together consist of over a 70 percent share of total export of Bangladesh in the initial period where it becomes over 75 percent in the end period without Articles of apparel of clothing access, excluding textile (848).

Articles of apparel, clothing access, excluding textile (848) lost its top ten positions of export share from the third period. Men's clothing of textile fabrics, not knitted (841) had the highest export share in the first and second period, but it is replaced by Articles of apparel of textile fabrics (845) from the third period until the end period, and reached its highest position regarding export share.

In the case of import specialization, 67 out of 227 industries were specialized in the initial period 1996-1999, and the number becomes 78, 76 and 84 in the period 2000-2003, 2004-2007, 2008-2011 respectively. Bangladesh import products mainly belong to the category of commodities for further production and the support of the exporting sector.

The second objective was to analyze the transformation of the pattern of trade specialization in Bangladesh and to answer the question to what extent the pattern of trade specialization has been transformed during the last 16 years.

From the Galtonian regression analysis of export specialization, we can conclude that the extent of specialization increases for all periods. The analysis of the longer periods (IV-I and IV-II) shows that Bangladesh experienced a very small level of diversification and changed its export specialization. But, in the case of the shorter period (IV-III), the economy becomes more specialized in the area of specialization where Bangladesh is already specialized and we can point out that the export specialization of Bangladesh is relatively stable, meaning that the relative position of industries changed a little. The analysis of import specialization showed us that the import is more diversified than the export, but both are relatively stable in the entire study period.

From the empirical analysis presented in this paper, we can understand that the economy of Bangladesh relies heavily on the garment and its supporting industries. Also, a few agricultural products, leather and leather goods also contributed to the total export share, but in a smaller amount.

In conclusion, Bangladesh is largely dependent on the garment and its supporting industries, and it is necessary to diversify its export basket. This would be beneficial for the further economic development of the country, since depending on a narrow export basket can cause export instability which arises from inelastic and unstable global demand. Further diversification in the higher value-added products with backward and forward linkage of the garment industry is needed to make it more competitive in the world market. 


\section{REFERENCES}

Balassa, B. (1965). Trade Liberalization and Revealed Comparative Advantage. Manchester School of Economics and Statistics, 33 (1), 99-123.

Bayarjargal, D. (2012). Revealed Comparative Advantage of Mongolia, 1996-2007. Masters' thesis, Department of Economic Development and Policies, Graduate School of International Cooperative Studies, Kobe University, Japan.

BBS (2011).Statistical Year Book of Bangladesh, Bangladesh Bureau of Statistics, Statistical Division, Ministry of Planning, Government of the People's Republic of Bangladesh, Dhaka.

Bernatonyte, D and Normantiene, A. (2009). Estimation of Trade Specialization: the case of the Baltic States. Economics of Engineering Decisions (2), 7-17

BGMEA (2013). Bangladesh Garment Manufacturers and Exporters Associations, Retrieved June 5, 2013, from http://bgmea.com.bd/home/pages/aboutus\#.UdvtR_1AQv4

BOI (2013). Foreign Direct Investment in Bangladesh (1971-2010), Board of Investment, Prime Minister's Office, Government of the People's Republic of Bangladesh.

BSCIC (2013). Bangladesh Small and Cottage Industries Corporation, Retrieved from http:/ / www.bscic.gov.bd/index.php?option=com_content $\&$ view $=$ article $\& \mathrm{id}=52 \&$ Itemid $=116 \&$ lang $=\mathrm{en}$

Cantwell, J. (1989). Technological Innovation and Multinational Corporations. Oxford: Basil Blackwell.

Dalum, B, Laursen, K and Villumsen, G (1998), Structural Change in OECD Export Specialization Patterns: de-specialization and 'stickiness. International Review of Applied Economics, 12(3), 423-443.

DILF (2000). Dhaka International Trade Leather Fair, Export Promotion Bureau, Dhaka 2000, p. 16
ETA (2013). Empirical Trade Analysis. Retrieved June 5, 2013, from http://www2.econ.uu.nl/users/marrewijk/eta/index.htm

Haque, M (2013). Leather Goods Export Gathers Pace on Value Addition, New Age, The Out Spoken Daily, Friday, January 18, 2013.

Laursen, K. (1998). Revealed comparative and the Alternative as Measures of international specialization. DRUID Working Paper. No. 98-30. Danish Research Unit for Industrial Dynamics (DRUID), Retried from http://www.druid.dk/wp/pdf_files/98-30.pdf

Laursen, K. (2000). Do export and technological specialization patterns co-evolve regarding convergence or divergence? Evidence from 19 OECD countries, 1971-1991. Journal of Evolutionary Economics 10, 415-436.

Sanidas, E and Shin, Y. (2006). Comparison of Revealed Comparative Advantage Indices with Application to Trade Tendencies of East Asian Countries, Department of Economics, Seoul National University.

Uchida, Y, and Cook, P. (2005). The Transformation of Competitive Advantage in East Asia: An Analysis of Technological and Trade Specialization. World Development 33(5), 701-728

Ullah, M.S., and Inaba, K. (2012). Dynamics of Comparative Advantage and Export Potentials in Bangladesh. The Ritsumeikan Economic Review, 61(4), 471-484

UNCTADSTAT. (2013), The United Nations Conference on Trade and Development. Available from URL: http://unctadstat.unctad.org/ReportFolders/reportFolders.aspx

World Bank. (2013). World Development indicators. World Bank: Washington, DC. 
How to Cite: Sikdar, M. M. H. (2019). An Analysis of Trade Specialization in Bangladesh, 1996-2011. American Journal of Trade and Policy, 6(3), 85-94.

\section{SOCIAL SCIENCE RESEARCH NETWORK}

2171 Monroe Avenue, Suite 203, Rochester, NY 14618, USA

http://www.ssrn.com/en/

SSRN Link: http://www.ssrn.com/link/American-Journal-Trade-Policy.html 